\title{
Identidade e Economia (I): Espelhamento, Pertencimento, individualidade
}

\author{
Wanderley Codo ${ }^{1}$ \\ Universidade de Brasília
}

\begin{abstract}
RESUMO - Partindo de uma definição de identidade como a construção social de igualdades e diferenças, constatamos a necessidade lógica de construção de equivalências para o processo de formação da identidade. O que nos autoriza a investigar teoricamente os vínculos entre identidade e economia, baseado na constatação de que ambos os territórios se estruturam a partir das relações de troca. Uma observação comparada do desenvolvimento econômico e da evolução das identidades possíveis nos leva a postular três formas possíveis de construção da identidade: Espelhamento, pertencimento e individualidade, que correspondem, por sua vez a três momentos de desenvolvimento das relações de produção: tribal, escravismo e capitalismo. As possíveis implicações teóricas destas formulações são discutidas.
\end{abstract}

Palavras-chave: economia, Psicologia Social; identidade; dialética.

\section{Identity and Economy (I): Mirroing, Belonging, Individuality}

\begin{abstract}
Considering identity like a social construction of equalities and differences we notice the logical demand to the construction of equivalence in the process of identities formation, what enable us to inquire about relations between identity and economy, based on the assumption that both of theoretical territories are based on exchange relationships between the social agents evolved. Observing comparatively the economical development across the history and evolution of the possibilities of identities expression we postulate three different possible identities, witch we call, mirroring, belonging and individuality, corresponding to three different moments of economical development: tribes, slaveries and capitalism. Possible implications of this theoretical framework are discussed.
\end{abstract}

Key words: economy; Social Psychology; identity; dialectic.

Identidade quer dizer etimologicamente a mesma entidade e o sentido etiológico não se desgarrou de sua etimologia, falamos em algo como identidade masculina (sou igual aos homens, ou os homens somos iguais) identidade nacional (sou igual aos brasileiros, ou os brasileiros somos iguais) etc..

Estamos, portanto perante a construção de igualdades, $\mathrm{eu}=$ professor, $\mathrm{eu}=$ brasileiro, $\mathrm{eu}=$ homem... etc..

Valerá a pena explorar um pouco mais este aspecto lógico da questão. Tomemos uma igualdade simples, em sua forma mais geral, seja $\mathrm{A}=\mathrm{B}$.

Esta afirmação é um absurdo lógico. Se A fosse igual a $\mathrm{B}$, não seria possível distingui-los entre si, A seria A ou B seria $\mathrm{B}$, o único portanto que poderíamos afirmar é que $\mathrm{A}=$ $\mathrm{A}$ e $\mathrm{B}=\mathrm{B}$, o que por sua vez seria constatar o óbvio, então $\mathrm{A}$ $\cong \mathrm{B}$, o que torna afirmação $(\mathrm{A}=\mathrm{B})$ uma mentira.

Se dissermos, Joaquim $=$ Homem, ou não poderíamos reconhecê-lo como diferente dos outros homens, e ai não seria Joaquim, ou não poderíamos diferenciar os homens dele, e todos os homens se chamariam Joaquim, ou estaríamos mentindo (?).

1 Endereço: Universidade de Brasília. Instituto de Psicologia. Campus Universtário Darcy Ribeiro. CEP: 70910-900. Brasília-DF. E-mail: trabalho@tba.com.br
O exercício acima é hilário. Todos sabemos que a expressão de igualdade, na verdade não é bi-polar, mas sim tripolar. Ao dizer que $\mathrm{A}=\mathrm{B}$, na verdade estamos dizendo que A tem características $\mathrm{X}$ e que $\mathrm{B}$ tem as mesmas características $\mathrm{X}$, o que os iguala, enquanto outras características os distinguem. Assim, A é uma letra do alfabeto romano, B também, portanto A é igual a B. Assim o nosso Joaquim conquistou direito à sua existência, Joaquim tem características que o igualam a um Homem e outras que permitem reconhece-lo como uma unidade. O nosso esquema ficou assim:

$\mathrm{A}=\mathrm{X}, \mathrm{B}=\mathrm{X}$, portanto $\mathrm{A}=\mathrm{B}$.

Construiu-se um esquema de equivalência, continuando com o Joaquim, teríamos algo assim:

\begin{tabular}{|l|l|l|}
\hline \multirow{5}{*}{ Brasileiro } & \multirow{5}{*}{ Joaquim = A } & Outros brasileiros \\
\hline Homem & Outros psicólogos \\
\hline Professor & Outros homens \\
\hline Psicólogo & Outros professores \\
\cline { 1 - 1 } Budista & Outros budistas \\
\hline Admirador dos Beatles & & Outros beatlemaniacos \\
\hline Etc... & Etc.... \\
\hline
\end{tabular}

Por sua vez, diferente de Homens, não brasileiros, professores, não psicólogos, budistas, não professores. Mesmo que Joaquim fosse assim tão pobremente caracterizado, as 
combinações possíveis seriam infinitas, ao final teríamos um Joaquim que poderia se intitular sem risco de um Indivíduo (em maiúsculo).

Por isto Ciampa (1994) pode nos ensinar que identidade se pensa sempre em um jogo de igualdade e diferença. Homem, igual a outros homens, brasileiro, igual a outros brasileiros, automaticamente diferentes dos homens não brasileiros e das mulheres brasileiras, e assim, per omnia.

O exercício de lógica amadora foi apenas para demonstrar que ao falarmos de identidade estamos falando necessariamente de equivalências, ou seja, de troca. Tornando o nexo mais claro: Para trocar é preciso que haja equivalência, que coisas comuns encontrarei entre o feijão e o arroz para que possa trocá-los? Para eqüivaler é preciso trocar, quantos quilos de arroz correspondem a um quilo de feijão? Equivalência e troca são conceitos siameses, um não sobrevive sem a presença e/ou a intima relação com o outro.

Eis o que nos permite falar em identidade (a mesma entidade) para um indivíduo. $\mathrm{O}$ que seria rigorosamente um absurdo. Trocar é construir relações de igualdade entre as diferenças. Portanto, perguntar sobre a identidade possível é perguntar sobre as equivalências possíveis ou, o que é o mesmo, sobre as trocas possíveis. Não posso dizer que sou um borbohominideo simplesmente porque não existem (a quanto se saiba) híbridos de borboletas e homens à disposição com que eu possa me equivaler, trocar algumas características.

As linhas acima foram calcadas em Karl Marx, nos Grundisses (1857-1858, 1992). Preocupado em compreender o dinheiro, Marx escreveu:

"A dependência mútua e generalizada dos indivíduos reciprocamente indiferentes constitui o seu nexo social. Este nexo social se expressa no valor de troca e apenas neste a atividade própria ou o produto se transforma para cada indivíduo em uma atividade ou em um produto para ele mesmo. O indivíduo deve produzir um produto universal...Por outra parte o poder que cada indivíduo exerce sobre a atividade dos outros ou sobre a riqueza social, o possui enquanto é proprietário de valores de troca, de dinheiro. Seu poder social, assim como seu nexo com a sociedade (o indivíduo) leva consigo no bolso ...".

Quantos dinheiros convivem dentro do dinheiro? $\mathrm{Ou}$ melhor, quantos significados diferentes pode ter o dinheiro? A resposta é curta: todos, o dinheiro pode assumir qualquer significado, e este não é um fenômeno imputável à nossa subjetividade, abstrato sim, mas não subjetivo.

Vamos mais devagar. Primeiramente, porque o dinheiro pode assumir qualquer significado?

Uma batata é uma batata, uma caneta é uma caneta. O professor de matemática nos alertava de que não se pode somar, dividir, multiplicar batatas com canetas. No entanto é isto o que acontece em nosso mundo, quotidianamente trocamos tudo com tudo, coisas muito diferentes entre si, no mercado. Você planta batatas, vai ao mercado, vende e compra canetas, ou o que mais lhe interessar.

A mágica é simples, se estabelece uma relação triangular, ao invés de se comparar para efeitos de troca a batata e a caneta, se compara a batata com algo que por sua vez é comparável à caneta. Este algo é o dinheiro. As coisas se passam assim:

\begin{tabular}{|l|}
\hline Batata \\
\hline Caneta \\
\hline Livro \\
\hline Vinho \\
\hline Computador \\
\hline Corte de cabelo \\
\hline Etc.... \\
\hline
\end{tabular}

\begin{tabular}{|l|l|}
\cline { 2 - 2 } & Batata \\
\cline { 2 - 2 } DINHEIRO & Caneta \\
\cline { 2 - 2 } & Livro \\
\cline { 2 - 2 } & Vinho \\
\cline { 2 - 2 } & Computador \\
\hline & Corte de cabelo \\
\hline Etc...... \\
\hline
\end{tabular}

Reencontramos o mesmo quadro que aplicávamos acima ao Joaquim. Tenho batatas que valem tantos dinheiros, você tem canetas que valem outros tantos dinheiros, eu vendo e compro, você vende e compra. Agora tudo é comparável com tudo, tudo se divide, se soma, se multiplica com tudo. Com isto o dinheiro pode assumir e assume todos os valores, todos os significados. $\mathrm{O}$ que você tem no bolso? $\mathrm{O}$ jantar de Domingo? a despesa da semana? o vestido novo da filha? o sofrimento de ver perder o time de futebol do coração? a camisa que vai provocar elogios dos amigos? Tudo isto e qualquer outra coisa. Ao mesmo tempo você não tem nada no bolso, um pedaço de papel, uma abstração, o dinheiro é essencialmente abstrato, pode representar tudo e não é nada.

Abstrato sim, invenção dos homens, sem dúvida, mas não subjetivo, no sentido de que suas propriedades de troca, de assumir valor, não depende do sujeito, mesmo que eu rasgue dinheiro (já se disse que quem rasga dinheiro é louco) estarei rasgando um valor objetivo, $5 \mathrm{~kg}$ de batata, 10 canetas, um ingresso para o Maracanã, uma noite no motel.

Eis o que Marx constata quando afirma que carregamos o nosso nexo com a sociedade no bolso. Construímos nossa identidade social como indivíduos na medida em que dispomos de um nexo universal, o poder de troca de tudo com tudo, de todos com todos, troca universal, equivalência universais, identidade/individualidade universal.

Olhe para você, quem é você?

\begin{tabular}{|c|c|c|}
\hline $\begin{array}{l}\text { Calça Jeans comprada em uma } \\
\text { pequena loja de griffe no } \\
\text { melhor shopping center de sua } \\
\text { cidade. }\end{array}$ & \multirow{6}{*}{$\mathrm{OU}$} & $\begin{array}{l}\text { Calça jeans comprada em uma } \\
\text { liquidação, em um magazine } \\
\text { 'popular' }\end{array}$ \\
\hline $\begin{array}{l}\text { Carro do ano com todos os } \\
\text { acessórios que você sequer } \\
\text { sabe para que serve. }\end{array}$ & & $\begin{array}{l}\text { Bicicleta, um pouco } \\
\text { enferrujada }\end{array}$ \\
\hline $\begin{array}{l}\text { Morando em uma cobertura de } \\
\text { um bairro nobre. }\end{array}$ & & $\begin{array}{l}\text { Morando de aluguel em um } \\
\text { condomínio, apartamento } \\
\text { quarto e sala. }\end{array}$ \\
\hline $\begin{array}{l}\text { Empregada doméstica de } \\
\text { avental branco te trazendo um } \\
\text { suquinho. }\end{array}$ & & $\begin{array}{l}\text { Faz você mesmo um macarrão } \\
\text { com pouco molho depois que } \\
\text { sai do serviço. }\end{array}$ \\
\hline $\begin{array}{l}\text { Frequientando festas vestido/a } \\
\text { de gala no Sábado à noite. }\end{array}$ & & $\begin{array}{l}\text { Freqüenta o boteco do seu José } \\
\text { onde toma uma cerveja, às } \\
\text { vezes come uma coxinha. }\end{array}$ \\
\hline $\begin{array}{l}\text { Arranhando um joguinho de } \\
\text { tênis com os amigos. }\end{array}$ & & $\begin{array}{l}\text { Assiste angustiado o jogo do } \\
\text { teu time pela televisão. }\end{array}$ \\
\hline
\end{tabular}


Alguma dúvida que estamos falando, também de identidades diferentes? Alguma dúvida que as características dos dois personagens acima carregam as marcas da diferença de dinheiro que tem? Não estamos dizendo que apenas o dinheiro que carregamos no bolso é responsável pela nossa identidade, mas é inegável que o vil metal tem um papel importante na definição que fazemos de nós mesmos, na forma como nos reconhecemos no espelho, na nossa identidade.

Um comerciante sabe muito bem a que classes sociais quer servir e que categorias profissionais compõem aquela classe. Da mesma tecelagem saem os tecidos que vão montar as calças jeans que "cobrem as vergonhas" dos operários e dos executivos.

As calças dos operários saem da confecção direto para a loja, onde ficarão empilhadas, às vezes jogadas a esmo à espera do consumidor, o qual será recebido por uma vendedora mal-humorada que a enfia em um saquinho plástico e encaminha a vítima ao caixa.

A calça dos executivos faz um percurso mais longo, sai da fábrica para emoldurar as nádegas de modelos regiamente pagas, ou astros de futebol, para depois freqüentarem o horário nobre na televisão, as páginas centrais das melhores revistas, para depois encontrarem vendedoras bem treinadas, vestidas adequadamente, sedutoras, hábeis em construir embalagens/artefatos de papelão que bem poderiam freqüentar uma bienal de arte, e pronto, lá se vai a calça jeans a fazer o orgulho das nádegas do freguês, perdão, do cliente.

Um executivo usa calças jeans, mas sempre com um pedacinho de couro distintivo colado atrás, um operário usa calça jeans, e ponto.

Falamos de calças, mas poderíamos ter falado dos lugares que as duas categorias profissionais freqüentam, portanto dos relacionamentos sociais que se estabelecem, o casamento de uma balconista com um filho de uma rica família ligada à construção civil é tão improvável que freqüenta as telas da última novela da Globo.

Outros modos de falar, de andar, de se comportar. Um modo de falar, andar e se comportar que acaba compondo a identidade de cada um de nós.

Centrado sobre o modo como as trocas se organizam no sistema capitalista, Marx encontra ali a forma como as individualidades se organizam. A construção histórica do dinheiro como equivalente geral permite a troca geral, de tudo por tudo, todos por todos, o que constrói a individualidade universal, a partir e por causa da troca universal. Se assim é, segue-se que outros modos de troca organizam outros modos de ser, dizemos nós, outras formas de identidade.

Voltaremos a esta questão mais à frente. Por ora basta sublinhar que Marx construía um arsenal para a economia política, obrigado a enfrentar relações de troca (o dinheiro), deparou-se com a individualidade. Para nós o percurso é oposto, obrigados pelo território grisé da psicologia social, a enfrentar a construção do indivíduo, somos conduzidos por Marx a encarar as relações de troca.

A inversão dos objetivos obriga a uma mudança de trajetória, para Marx, era possível restringir a troca à mercado- ria, a equivalência ao seu representante geral, o dinheiro. Já nós somos obrigados a estender o conceito de troca, não apenas ao seu universo da economia estrita, mas à relação entre os humanos de uma forma genérica.

Há que reconhecer que existe uma economia das trocas simbólicas, se quisermos, uma psico/sócio/economia permeando as relações sociais. Senão vejamos:

Que seja a constituição do menino e da menina.

Tempos houve em que modelos havia; menino joga bola, menina brinca com boneca; menino abre as pernas ao sentar-se, menina fecha; menina não briga, menino não apanha na rua.

A construção social da menina e do menino encontra um organismo biológico, para nossos efeitos, vazio de valores ligados a gênero, passível de ser preenchido pelos projetos efantasias dos pais: "da minha filha quero que seja um bom partido, uma moça prendada, capaz de fazer feliz ao mancebo que dela se aproxime", "de meu filho quero a virilidade, a competência, a garra para disputar seu espaço no mercado".

Estes espaços de identificação se constroem de forma autocrática em pelo menos dois sentidos; não estão sob a forma de decisão do pimpolho, porque a ele não é acessível o papel que homens e mulheres ocupam na sociedade que ele ainda não viu e também porque não é parte de uma decisão consciente que os seus pais pudessem tomar, à frente dos pais agoniados surge um modelo pronto e acabado de gênero, ao qual cabe conformar seus rebentos, no mais ficam as idiossincrasias da personalidade de cada um a transmitir sentimentos de competência ou incompetência na formação da prole.

"O menino" moldado em casa ganha a rua como "um menino", outras diferenças se revelam no confronto deste ser social com outros e outras; comparações e confrontos vão compondo um mosaico único que permite a cada um dos projetos de pessoa estruturar um desenho único que chamamos de identidade, outras restrições, outros reconhecimentos.

Falamos de identidade de gênero, se quisermos compreender como ela se constitui chegaríamos a um esquema mais ou menos assim:

\begin{tabular}{|c|c|c|}
\hline Brincar de casinha & \multirow{4}{*}{$=$ menina $=$} & Mariazinha \\
\hline Cuidar & & Helena \\
\hline Não dizer palavrão & & Outras meninas \\
\hline Etc. & & Etc. \\
\hline
\end{tabular}

A representação, propositadamente caricata, para ganhar força pedagógica, no mundo real não tem começo nem fim. Cada igualdade construindo equivalências, trocas, diferenças, igualdades. Por isto podemos ser UM.

Se compreendermos, portanto que:

A operação lógica; $\mathrm{A}=\mathrm{X}, \mathrm{B}=\mathrm{X}$, portanto $\mathrm{A}=\mathrm{B}$. $\mathrm{A}$ operação psicosocial; Joaquim $=$ Homem $=$ Benedito. $\mathrm{E}$ a operação econômica; Mercadoria $=$ dinheiro $=$ outra mercadoria 
São a mesma operação. Então, identidade se explica pela economia, se definirmos economia como a ciência que estuda as relações de troca.

Até agora estivemos constatando uma similaridade nos mecanismos de funcionamento, podemos afirmar que a construção de identidade opera da mesma forma que as relações de troca/equivalência operam. Veremos agora que não se trata de mera coincidência.

$\mathrm{O}$ ato animal é um ato que se fecha em si mesmo, composto se um circuito que vai e volta em direção a um objeto, e nada mais. Comer ou beber, para um animal não humano começa no organismo com a fome ou sede, encontra a comida/água, as necessidades satisfeitas e a água permanece ali, na natureza e o animal segue seu curso. O mesmo gesto, para o ser humano se espalha para além, muito além de si mesmo; Comer ou beber pode ser uma homenagem, um protesto político, um jogo de sedução, uma peça publicitária, o exercício do poder, é, em potência, diria Aristóteles, tudo isto ao mesmo tempo. Via linguagem e consciência, por mecanismos que não nos interessam aqui, o gesto ganha transcendência, se abre além de si mesmo. O que sim nos interessa é que o gesto humano é humano na medida em que estabelece entre quem o realiza e o alvo um circuito aberto, infinito, além e apesar de si mesmo. Comer ou beber passam a receber inputs de todo o planeta e a enviar outputs para todo o planeta. Comer um hambúrguer ou caviar, beber água de torneira ou Perrier encontram prontos todo um sistema de outros significados, outros comeres e beberes já feitos, historicamente construídos que inserem o gesto em todo um sistema de significados, intrincado, complexo, eterno; por sua vez porta os seus significados particulares, a aceitação de um convite jantar traduz outros códigos, carrega outros significados que passam a ser incorporados ao gesto animal, como unha e carne, dele fazendo parte tal e qual a mastigação.

Diremos, à guisa de síntese, que o gesto humano é transcendente, maior do que ele mesmo. $\mathrm{O}$ modo de construção da transcendência, qualquer que ela seja, passa necessariamente pela construção do outro dentro do gesto. Demonstremos isto.

Que seja ainda um gesto banal: beber água.

Uma torneira quotidianamente mal fechada em um canteiro de obras, o trabalhador se abaixa, as mãos em concha, o líquido escorre, o sorver é longo, a respiração se altera.

Uma garrafa retirada de um freezer, um copo apropriado, um homem uniformizado de branco traz a garrafa de água (sem gás) até um cliente sentado, garçom, mesa, cadeira, copo, outros funcionários envolvidos, tudo a emoldurar um reles copo d'água.

A necessidade poderia ser idêntica, o que diferencia os gestos são os outros que ele carrega dentro de si. Um trabalho duro no primeiro gole d'água, uma pausa de laser no segundo; classes sociais distintas, inserções sociais distintas, marcas de status, valores, posições distintas. Os outros que comparecem ao gesto são outros em cada uma destas situações.

O que se demonstra aqui é que afirmar o gesto humano como transcendente é sinônimo de afirmar que o gesto se carrega de seus outros possíveis. Como se dá este espelhamento infinito? Exatamente nas relações de troca.

Voltemos ao gole d'água. Dobrar os joelhos na torneira e/ou levantar o dedo indicador reivindicando o garçom insere o ator em uma comunidade (trabalhadores ou madames) porque, e apenas porque estabelece equivalências, trocas no sentido em que a viemos definindo.

De forma esquemática, o gesto animal se resolve assim:

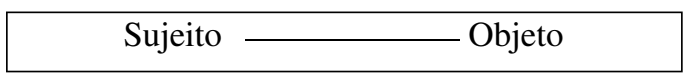

Já o gesto humano obriga a pensar em:

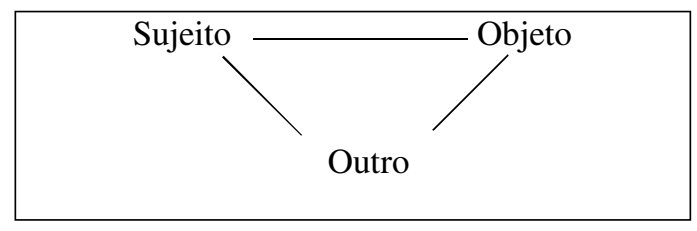

Tanto faz, de um ponto de vista da construção de identidade, se no lugar do outro está um ser humano em carne e osso, um grupo social, uma classe econômica, uma empresa, uma religião. Inclusive ocupa amiúde o lugar do outro os objetos, qualquer objeto.

É que a atividade imanta socialmente os objetos com os significados construídos história adentro. A caneta que repousa sobre minha mesa é parte do 'equipamento' que a empresa me fornece para o trabalho, ou foi uma homenagem de meus colegas por anos de batalha no mesmo emprego, ou foi presente daquela moça no meu aniversario, os objetos que nos rodeiam, com o qual convivemos são povoados de fantasmas.

Até agora, o que foi possível investigar, coloca a questão da troca, das equivalências, no cerne mesmo da questão da identidade. Ou ainda percebe a identidade como construída por e pelas relações de troca. Os nexos entre identidade e economia, portanto, devem ser investigados não como mais uma forma de tornar-se um; como pertencer a uma religião ou a um clube de futebol, mas como uma categoria fundante do fenômeno que nos propomos a investigar, trata-se de um nexo etiológico, não apenas uma associação heurística.

É a economia, entendida aqui como a ciência que estuda as relações de troca que explica a nossa identidade, entendidas por sua vez, as relações de troca estendidas desde a operação econômica estrito-senso (compra e venda) até as trocas simbólicas. Da compra de uma calça Jeans até aos olhares furtivos entre dois adolescentes em uma festa, tanto um como outro permite ao Self o seu espelho, pelo espelho o seu outro, pelos outros, o desenho de si mesmo.

Estamos obrigados a investigar como as relações de troca ocorrem, que espelhamentos produzem, se quisermos avançar na compreensão da identidade.

Como evoluem os modos de ser UM?

A pergunta agora fica sendo, quais são as possibilidades de troca que a história vem propiciando, dito de outro modo, 
como, cada sistema social disponibiliza uma rede de trocas possíveis.

\section{Espelhamento}

Na tribo, a produção é a do grupo, não há excedente para a troca.

Uma comunidade que se basta a si mesmo, segundo a definição de Gianotti, a tribo troca entre si, estabelece papeis que se delimitam em seu interior quer atendendo aos ditames da sobrevivência quer na construção autônoma de um sistema autônomo de linguagem, crenças, regras, valores.

Em um sistema social assim, cada indivíduo existe na inter-relação com o outro imediato, cada um dos seres em um jogo de espelhamento a encontrar um espaço de convivência: Fazem parte da teia também os antepassados, mas vividos ou imaginados enquanto relações sociais imediatas. A família, a divisão de trabalho, por exemplo, entre o Xamã e os outros, os animais, cada qual se reflete na coletividade e reflete a si mesmo, se constrói neste duplo jogo onde sou para o outro na simetria em que o outro é para mim. Marx dizia o indivíduo pertence à tribo como a abelha pertence à colméia. Chamaremos a esta individualidade possível de espelhamento.

Fora da tribo o outro não é. Neste contexto qualquer uso que se faça da tribo que não é aquela se explica, pode, por exemplo, ser parte da refeição como qualquer fruta que se apanhe na arvore mais próxima sem que nenhum conflito moral surja no horizonte, ou pode ser incorporada como membro com espaço garantido na constelação de papeis da tribo, da mesma maneira, a depender do sistema de crenças e da divisão de trabalho que a história daquele agrupamento construiu. Ou ainda, a história ali é a historia daquele agrupamento.

Nas relações de espelhamento, ferir um membro do grupo é ferir a mim mesmo, agradar, acolher, presentear a cada um deles é fazer a benesse para mim mesmo. Sou na medida do meu grupo, sou na relação direta e imediata com o outro.

Vejamos porque: As relações sociais na sociedade primitiva foram estudadas de perto por Gianotti, em 'Trabalho e reflexão', baseado por sua vez nos achados de Levi-Strauss (Gianotti, 1983). Vejamos ao que chegou o filósofo.

\footnotetext{
"Uma sociedade é autônoma quando for capaz de repor a si própria', mesmo que hajam relações mais ou menos contínuas com outras sociedades, 'o corte opera entre sociedades que conseguem sobreviver sem escambo ou comércio e aquelas que, necessitando destes, passam a integrar-se em um todo mais amplo" (p. 132).
}

Gianotti vai encontrar na dádiva o modo como as relações de troca se perfazem na tribo, e nos alerta para não confundir dádiva e troca, mesmo que as primeiras sejam recíprocas. No valor de troca, as coisas encontram entre si algum tipo de equivalência, na dádiva são os carecimentos do outro, as necessidades, reais ou simbólicas que comparecem como motor do gesto de doar. É o outro que se busca e que se atinge na dádiva, porque é do outro que o membro da tribo carece. O objeto não comparece como autônomo, independente da relação concreta entre produtor e produto, como no universo da mercadoria, ao contrário, comparece como representante imediato do produtor/doador na vida do consumidor/receptor da dádiva, a dádiva mira a sociabilidade, se perfaz e se concretiza enquanto sociabilidade, eu e o meu produto, o outro e o produto do outro como seres indistinguíveis.

Diremos nós, com Marx, a produção e a troca são produção e troca de valores de uso, e o uso repõe no objeto o utilizador imediato, não um outro valor genérico. $\mathrm{O}$ uso realiza o usuário que realiza o objeto utilizado, permeado pelo outro imediato quando o objeto a ser utilizado é dádiva.

Voltemos a Gianotti: "A cisão do produto pressupõe a existência de um nós, também dividido em duas partes, a primeira da objeto da qual o ego se identifica de imediato, a segunda da qual ele se distancia, ao mesmo tempo em que reconhece nela uma semelhança, pois ambas constituem momentos de um mesmo processo produtivo global".

Com mais vagar, a produção estabelece um metabolismo entre o produtor e a natureza (a primeira identificação), o Self depositado no objeto se desprega do sujeito produtor para encontrar o outro, receptor da dádiva, também ele depositando no produto alheio suas carências, portanto suas identificações. Mas a produção é do outro, portanto ao me reconhecer no produto alheio é com o produtor alheio que as minhas identificações ocorrerão; ao encontrar o valor de uso para o outro a dádiva transforma o carecimento da coisa no carecimento do outro, fecha o circuito de uma sociabilidade, que se não é imediata, (é apenas porque é mediatizada pela natureza humanizada ).

"Esse nós pressuposto...promove... o amalgama das relações entre as pessoas com as relações entre as coisas...A reposição dessa estrutura é assegurada pelo produto como oferta, coisa sacrificada para o outro...portanto qualquer valor de uso, desejado pelo outro, pode vir a cumprir a mesma função de penho"".

Nos avisa o filósofo, pela dádiva, o que era perda se transmuda em poder. Ao dar mais estabeleço mais vínculos, concorro a maior reciprocidade, outros mais vão se acumulando na minha rede social. Ao perder, pela dádiva, o indivíduo ganha, por que é o outro que a dádiva visa, e são os outros que comparecem na trama social do doador.

Partimos da premissa de que os modos como as trocas, reais ou simbólicas se estruturam determinam o modo como as identidades se estruturam, encontramos uma sociedade que troca apenas entre si mesma, cada palavra, cada produção de comida, cada mito, se dirige apenas ao coletivo imediato, encontramos um modo de construir a identidade baseada no espelhamento, de si no outro, de si na coletividade imediata, um ser que se constrói na relação vis-à-vis com o seu outro.

A palavra chave aqui é o vínculo imediato, a troca imediata, o que não quer dizer fechada, como apontávamos acima para os animais, o esquema ainda inventa um outro, mas um outro que se refaz simbolicamente, através da lingua- 
gem e da consciência como modos de ser do outro imediato, a comunidade, a esposa, o grupo, os símbolos, signos, representam o outro imediato.

Um primeiro modo de construção da identidade, um primeiro nível onde as trocas ocorrem é a troca imediata, onde o outro comparece como imediato.

Este modo de ser surgirá sempre que as trocas se mostrarem circunscritas, um grupo fechado que troque apenas consigo mesmo. Indivíduos A, B, C, D, E convivendo em um espaço restrito, co-satisfazendo suas necessidades (do estômago ou do espírito), construindo um jogo de espelhamentos onde o outro é visível e imediato, prescinde de abstrações.

Uma identidade sim, mas plasmada no grupo, sou o que os meus sãos, sofro se sofrem, sinto prazer se eles sentem. Ou ainda, e o que é o mesmo, me diferencio em um jogo de atividades, de trocas, a partir do grupo e para o grupo. Sou mais feio que, mais simpático que, mais inteligente que. Fronteira tênue entre identidade e identificação. Por exemplo, Severino ao revelar seu nome, no poema e na análise de Ciampa, primeiro, no sentido de fundador, exercício de igualdades e diferenças que me produz a partir da troca com os meus outros.

\section{Pertencimento}

Sociedades escravistas, feudais com este ou aquele grau de desenvolvimento ou peculiaridades na produção, material ou simbólica, estrutura-se com bases no pertencimento de uns sobre outros, nas palavras de Braverman, sociedades onde a divisão de classes operava entre possuidores e possuídos. $\mathrm{O}$ outro modo fundante sobre o qual se erige a identidade, portanto, será este; o pertencimento.

Comecemos por lembrar com Hegel que é inútil cair na armadilha que o escravo não é, que apenas o senhor seria, que o escravo comparece na relação como mero apêndice do senhor. O que Hegel ensina é que se trata de uma relação onde a identidade de um se perfaz pela identidade do outro; Senhor se projeta e se realiza vis-à-vis o Escravo, escravo se projeta e se realiza no Senhor, cada qual se constrói em relação mediatizada pelo outro.

Inaugura-se a este ponto a presença da mediação, claro, já poderia ser detectada na tribo, mas não no lugar de determinante do processo de construção da identidade, como aqui. Cabe-nos, portanto o exame desta mediação em estruturas sociais onde as pessoas pertencem umas às outras.

O que ocorre com as relações de troca nestas sociedades é uma relação de dependência entre uma comunidade organizada (família, feudo, reinado) e outra, mas ainda enquanto comunidades, e não como indivíduos singulares, como ocorrerá no capitalismo. Com este cenário, as relações de equivalência projetam nos produtos trocados a figura da comunidade em si mesma; assim, se uma relação de vassalagem se estabelece entre dois feudos, cada membro do feudo representado pelo seu senhor estará se reapresentando através daquela troca. Não é de se estranhar a fidelidade absoluta que o escravo ou servo dedica ao senhor, pela simples razão de que a minha existência só se reconhece pela existência ao senhor, fazer mal a ele significaria sofrimento ou morte para mim mesmo, defendê-lo passa a ser a defesa do modo como eu mesmo sou construído, a minha razão de ser; que se lembre que o contrário também é verdadeiro; trata-se de uma obrigação inelutável do senhor defender até a morte seu rebanho. Também não se estranha o forte apelo que se faz a símbolos, bandeiras, modos de vestimenta particulares para cada feudo ou família, não sou eu que me apresento na sociedade, é o meu grupo, macular nossa bandeira é macular a cada um de nós, razão mais do que suficiente para um duelo de morte.

Shakespeare, em Romeu e Julieta, nos brinda com um bom exemplo do que queremos demonstrar, literatura, é verdade, mas fiel ao seu tempo, como nos garantem os historiadores. Capuleto e Montechio são ameaçados de desaparecimento ao surgir o 'risco' de um amor entre os membros de seus respectivos clãs, a sociedade inteira se abala, o sujeito não pode existir apesar de seu grupo, suas vontades, seus desejos não são; o modo como se reconhecem é o modo como os seus senhores se reconhecem, carregam ódios e amores coabitados por todo o clã, costumes compartilhados, uma vasta rede de espelhamentos que reflete cada um a partir do outro e em oposição aos outros clãs, a adoção deste ou daquele hábito por um clã era razão suficiente para que o outro o abandonasse, a aproximação de alguém alheio a um deles bastava para que o outro o rejeitasse. Neste quadro, o Senhor é na medida dos seus servos, os servos são na medida do seu senhor, cada qual se projetando e se realizando no seu outro, comparecendo no tecido social mediado por ele.

Ser um privado de... (sustentado inteiramente por um patrono) assim se referiam, na idade média, as pessoas que por alguma razão se ofereciam ao jugo de um senhor poderoso; "Entrega de si em troca de tudo aquilo de que o corpo e a alma podem ter necessidade. E o direito para aquele que distribui os víveres de flagelar." (Áries e Duby, 1992).

"Abaixo do senhor, alguém, abaixo deste alguém algum outro, uma hierarquia rígida onde cada qual se projeta no outro e assim sucessivamente, quanto mais vasta a casa do senhor, maior seu poder e prestígio, maior portanto a capacidade de atrair vassalagem, mais valiosas as mulheres espalhadas por outros domínios, uma linhagem”.

No espelhamento, na comunidade primitiva, falávamos em um sistema de trocas/identidade imediato, o individuo se constrói e se reconhece em uma relação eu-grupo.

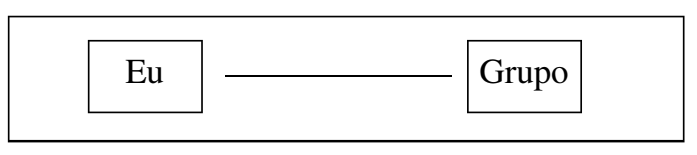

Aqui o grupo, grande família, clã, casa, feudo, aparece como mediação obrigatória entre os sujeitos.

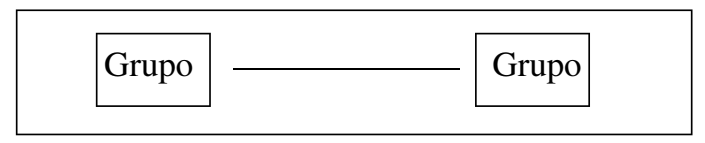

Psic.: Teor. e Pesq., Brasília, Set-Dez 2002, Vol. 18 n. 3, pp. 297-304 
Já que as trocas, materiais e simbólicas assumem características sistemáticas entre os grupos organizados, agora a identidade se conforma na relação entre o meu grupo e o outro. Claro, a primeira eschemata não desaparece, além da construção da minha identidade no meu grupo tenho a constituição da identidade do meu grupo perante o outro grupo. Agora, quando um indivíduo comparece no tecido social, comparece como representante de outros, emblematizado e emblematizando a figura do senhor. E é preciso ter um (ou ser um) caso contrário, o indivíduo não é.

O manto, as bandeiras, as vestes do senhor, família e criadagem são os sinais de si que comparecem no território do público como representantes da "entourage", da "casa grande".

\section{Individualidade}

O advento do capitalismo instaura a equação mercadoria-dinheiro-mercadoria, instala a possibilidade da troca de tudo por tudo, portanto, de todos com todos.

O reinado da mercadoria se atinge, sabemos através da transformação do trabalho mesmo em mercadoria, ou seja, a possibilidade de intercâmbio entre coisas se faz acompanhar do intercambio universal entre pessoas, cada qual troca com o outro, ou seja, cada qual vale por si. Surge o indivíduo como o compreendemos hoje, o direito (burguês) do cidadão, a psicologia (Codo, 1987).

Agora temos um equivalente geral, dinheiro, moeda universal capaz de (dentro da nação) fazer equivaler a tudo. Cada cidadão é livre, só isto torna possível a compra e venda da força de trabalho, dizem Marx e Engels, Cada um de nós é um, não se confunde e não se espelha em nenhum outro, ou o que quer dizer o mesmo, cada qual pode (em potência) trocar e se reconhecer, em tudo e em todos.

O casamento passa a ser uma questão de escolha, inaugura-se o amor individual, "a individualidade é a grande conquista histórica do capitalismo" (Engels, 1978).

Cultivamos espanto ou ódio pelo espelhamento ou pelo pertencimento, quem é pelo outro ou é do outro passa a ser execrado como não sendo; lhe falta caráter, "personalidade", maturidade.

Valor de uso e valor de troca fundidos em cada gesto, em cada palavra, em cada ação; se digo "Quero", se sinto "quero", se ajo como quem quer, o meu querer se apresenta imediatamente como meu, pessoal e intransferível e ao mesmo tempo como universal, mediado por todo o planeta, todos os homens e todas as coisas do planeta. A mediação universalizada pela troca universal, a possibilidade, portanto, de surgimento e operação do indivíduo igual a si mesmo.

Ser um passa a ser direito e desejo de todos. Não há muita novidade, é o mundo onde todos nós nos reconhecemos como sujeitos; basta olhar no espelho, ou para os lados para se ter exata noção do que estamos falando.

\section{À guisa de síntese}

Encontramos no modo como as trocas, materiais ou simbólicas, uma chave fértil para a compreensão da identidade, encontramos na História três formas básicas a partir do qual a identidade se constrói, pertencimento, espelhamento, individualidade. O que estamos afirmando é que estas são as únicas formas possíveis de construção social da identidade, todas elas ancoradas na forma como os humanos atingem a forma de sobreviver. A identidade, portanto, se explica pela economia.

Em um certo sentido, esta tese é evolutiva, já que mudam e/ou se ampliam as formas de reconhecimento de si mesmo na medida em que se ampliam os horizontes de troca: Dentro de um grupo, desenhando o espelhamento, entre grupos, desenhando o pertencimento, com toda a sociedade, definindo a individualidade moderna.

Mas é evolutiva apenas neste sentido. Nenhuma das formas de troca elimina a anterior, o espelhamento não desaparece da sociedade para dar lugar ao pertencimento, nem este à individualidade. $\mathrm{O}$ que ocorre se parece mais com a metáfora arqueológica desenvolvida por Foucault na Arqueologia do Saber, cada modo que a história encontra vai se acumulando sobre o modo precedente, e opera conjuntamente sobre os outros. Para falar outra vez com Marx, o novo modo de produção se constrói sobre o velho, não o elimina, encontrar-se-á sempre a sociedade velha operando dentro do útero da sociedade nova. Assim, encontramos estruturas sociais contemporâneas atuando sob a forma de espelhamento, como a família para o infante, ou a torcida organizada de futebol para os marmanjos, encontramos o pertencimento para os adolescentes, vide o fenômeno das gangues, ou no modo de funcionamento das máfias, encontramos a individualidade atuando em equilíbrio dinâmico e/ou conflito com estes modos. Eis o que torna o problema da identidade tão complicado.

Entender como operam estes modos na sociedade atual ou no desenvolvimento dos indivíduos contemporâneos pode ser útil para organizar um pouco a barafunda em que se encontra esta área de pesquisa, e quiçá possa a ajudar algo na compreensão dos dramas que a nossa sociedade vive. Mas esta é uma outra história, fica para uma outra vez.

\section{Referencias}

Ciampa A. da C. (1997). Identidade. Em: Lane, S. \& Codo, W. (orgs) Psicologia Social o Homem em movimento. São Paulo: Civilização Brasileira.

Codo, W., Hitomi, A. H., \& Sampaio,J. J. C. (1994). Indivíduo, trabalho e sofrimento - Uma abordagem interdisciplinar. Petrópolis, RJ: Vozes.

Marx, K. (1978). Obras Escogidas. Moscú. Editorial Progresso. Marx, K. (1978). Elementos Fundamentais Para La Crítica De La Economia Política - 2, Argentina, Siglo Veintiuno Editores, $9^{\mathrm{a}} \mathrm{ed}$. Marx, K. (1978) O Capital. Crítica da economia politica. Rio de Janeiro: Editora Civilização Brasileira.

Levi-strauss, C.(1970). O pensamento selvagem. São Paulo: Editora Universidade de São Paulo.

Giannotti, J. A. (1993). Trabalho e reflexão. São Paulo: Editora Brasiliense. 
Áries, P. \& Duby, G. (1992). História da vida privada. São Paulo: Companhia das Letras.

Engels F.(1978). Origem da família, propriedade e do estado. Em: Marx, K \& Engels, F Obras Escogidas. Moscú: Editorial Progresso.
Recebido em 15.02.2001

Primeira decisão editorial em 17.01.2002

Versão final em 16.09.2002

Aceito em 10.10.2002

\section{INTERESSADO EM AGILIZAR A TRAMITAÇÃO DE SEU MANUSCRITO?}

\section{Informações e dicas para os autores sobre aspectos de forma}

\section{O manuscrito é encaminhado para exame}

O manuscrito é revisto por consultores ad hoc, pelo Conselho Editorial e na secretaria da revista. $\mathrm{O}$ exame pode ser mais rápido se o manuscrito está bem escrito e se já foi bem revisto pelo autor (incluindo revisão ortográfica e de consistência na apresentação de referências).

Textos mal redigidos comprometem o exame de mérito do conteúdo. Manuscritos mal preparados ou mal redigidos são sumariamente rejeitados. Manuscritos que parecem potencialmente interessantes para publicação mas que devem passar por modificações substanciais podem ser candidatos a uma tramitação prolongada. Manuscritos com inconsistências na apresentação de referências têm a tramitação prolongada com a consulta aos autores para as devidas correções.

\section{Trecho selecionado do Manual da APA (4 $4^{a}$ edição)}

Conforme apropriadamente lembrado no Manual da American Psychological Association [APA] (1994), referências preparadas com acuidade são pontos a favor da credibilidade do autor como um pesquisador cuidadoso. De outro lado, conforme citado no Manual de APA (p. 175): "Uma referência incompleta e não acurada 'ficará impressa como um incômodo para futuros investigadores e um monumento ao descuido do escritor' (Bruner, 1942, p. 68)".

American Psychological Association. (1994). Publication manual of the American Psychological Association ( $4^{\mathrm{a}} \mathrm{ed}$.). Washington, DC: Autor.

\section{Informações e dicas para os autores sobre aspectos de conteúdo}

Na reformulação de seu manuscrito o autor deve procurar atender às indicações dos pareceristas que atuam como leitores críticos de seu trabalho. Quando o autor discorda das indicações, cabe argumentação - menos no sentido de afirmação categórica de razões pessoais de preferência e mais de apresentação de argumentos que justifiquem o mérito científico de sua posição. 